\title{
Issues and options in high country farming 1. Genesis of present situation
}

\author{
K.F. O'CONNOR ${ }^{1}$ and D. SCOTT ${ }^{2}$ \\ ${ }^{1}$ Centre for Mountain Studies, PO Box 84, Lincoln University, Canterbury \\ ${ }^{2}$ AgResearch, PO Box 60, Lincoln
}

\begin{abstract}
The symposium acknowledges the significance of the South Island high country and its pastoral use. Interest is focused throughout the symposium on pastoral practices, even though both the origins and the solutions to the present situation are much wider in scope. The first paper itself outlines physical, ecological, economic, technological and cultural influences at work over history and prehistory to give rise to the present situation. It notes the role of market forces, not just affecting wool prices in the traditional pastoral industry and in its renaissance in recent decades, but also affecting the demand for land for other uses and purposes. It describes role of myths and icons in the shaping of past and contemporary high country issues.
\end{abstract}

Keywords: high country, history, icons, land use, market forces, myths, pre-history

\section{Introduction}

The South Island high country is very much a part of New Zealand history and psyche. Like the mountains themselves, the high country looms large, perhaps disproportionately large, in our vision of our land and ourselves. The pastoral country, that which has been traditionally held in pastoral leases, constitutes about half the total high country of some 6 million hectares. Some three hundred pastoral runs on more than a tenth of the total area of New Zealand carry about $5 \%$ of the its total livestock load and generate some $3 \%$ to $8 \%$ of New Zealand's net farm income, depending on world prices for fine wool.

High country pastoral practices have been criticised for more than 100 years for their alleged effects on the tussock grasslands themselves, for some 50 years for their alleged influence on soil erosion and downstream flooding, and more recently for the alleged protection of biodiversity. Increasingly over the last 40 or 50 years the suitability of these lands for traditional pastoral use in their unimproved state has been questioned, and the values of other uses, both complementary and alternative, have been extolled.

The first paper outlines some of the physical and ecological, historical, technological and social influences which have generated the present pastoral situation, and which may also affect future options. Subsequent papers review the technical options, evaluating them, developing and directing emerging options, interpreting the soil and ecosystem context for sustainable management, and finally illustrating a participatory approach to science by outlining how farmers, scientists and resource managers learn to live with the hawkweed problem.

\section{Natural and cultural influences}

There is considerable geographic variation among different zones and sectors of the high country. Table 1 displays some of the unifying and diversifying forces that have worked on the high country to give rise to its current pastoral practices and some of the major issues that face us.

\section{Ecological genesis}

By geological time scales, the Southern Alps, with associated fold mountains to the east and north and block mountains to the south, are young in character, because mountain building and shaping have been continuing over recent millions of years to the present. Mountain building began in the Rangitata orogeny 24 million years B.P., with sandstones deposited from 200 million B.P. The Kaikoura orogeny, the major and continuing uplift of mountains, functioned from 6 million B.P. Metamorphosis of greywacke to schist in regional Otago, the Main Divide and Marlborough from that time has profound influence even now in landscape sculpture, rock weathering, and soil, vegetation and animal behaviour.

The isolation of the New Zealand land mass from Gondwana and its Australian neighbour has been complete since the late Cretaceous, 60 to 80 million B.P. This had effects on the evolution of our flora and fauna from anciently similar moist forest and shrubland origins. Evolution of New Zealand biota continued on its own, enriched from time to time with some islandhopping or wind-borne strangers, but limited in standing and distribution by the recurrent advances of ice during the Pleistocene, even to the four major advances of the last Ice Age, 13-, 17-, 50- and 103,000 years B.P. As forests were reduced in the Pleistocene and alpine grassland vegetation expanded, shrubby and herbaceous 
Table 1 Historical and technological milestones in the development of the South Island high country.

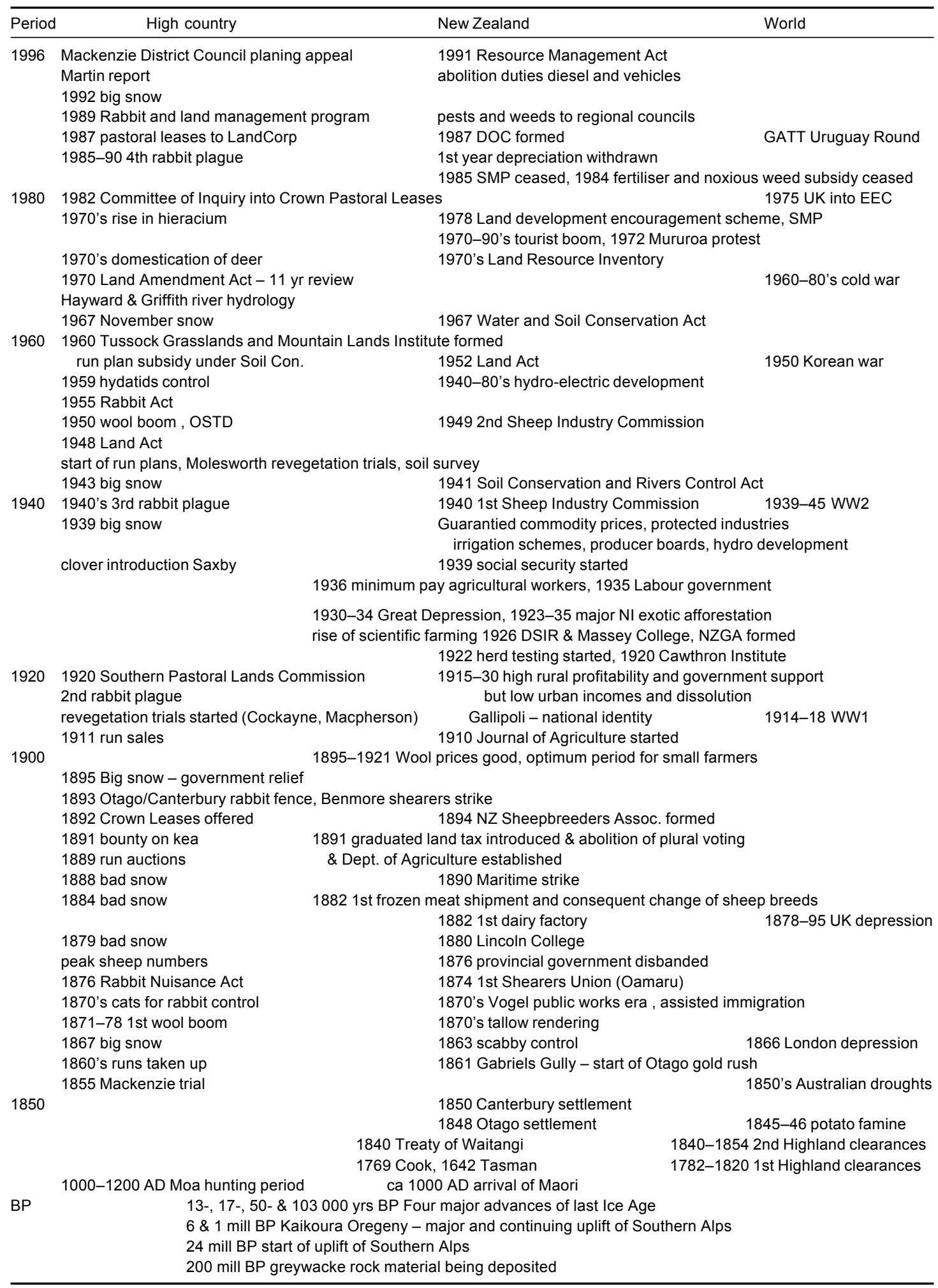


species became more prominent. After the last major ice advance, grasses and ferns dominated the pollen record at many localities, even in lowland South Island. As climates warmed again during the Holocene, forests expanded once more, more slowly in the south, more quickly as podocarp rather than beech. Although about 2,500 years B.P. fire permanently destroyed much of the forests of Central Otago (McGlone 1988), forests, with species largely deriving from residual Tertiary elements, occupied more than three quarters of the land area before human impact. The grasslands had retreated to the alpine zone. In summary, New Zealand grasses have not had long opportunity for evolution in other than alpine environments.

For a few hundred years, mankind gave them a brief evolutionary opportunity in some of the higher potential productivity zones of the montane and lowland forest. From 1000 years B.P., Maori fire deforested most of the eastern South Island, both mountains and lowlands. Chionochloa, the principal grass genus, and other grassland and herb field genera such as Aciphylla and Celmisia, with their main species development at high altitudes, were again free to move downwards from the alpine zones to reoccupy all but the driest previously forested land (Wardle 1991). None of their earlier evolutionary adaptations would have equipped them well, except as survivors in harsh environments. They could resist or recover from fire, some of them could even evade grazing. However, grasses that had dominated ungrazed alpine and penalpine tundras in the last glaciation were not evolved to be high producers and successful competitors at lower altitudes under the grazing impact that was to come in the last 150 years. This contrasts with the evolutionary history of Australian grasses and grasslands.

Having extended the grasslands and alpine vegetation at the expense of forest, in many cases to the coastal lowlands, early Maori hunters soon reverted to a littoral, food-gathering economy themselves. The high country was memorialised for them and their eventual successors in the eastern tall tussock grasslands that their fires created and maintained, in the stories of the greenstone trails, the songs of the Waitaha, and cave art of taniwha and moa. For hundreds of years afterwards their coastal middens accumulated testimony to the short term of a moa-hunting economy in the interior. What parallels does this suggest for pastoralism?

\section{Physical environment}

The high country is dominated by its physical environment. The topography is sculptured by successive recent ice ages. The mountains rise as a barrier to the prevailing westerly air-stream, leading to very marked rainfall gradients. As cyclonic lows move to the east, and the warming of the Foehn effect wanes, the southern highlands lie open to the antarctic blast, and eastern lowlands have only local benefit of mountain barriers. This is a mountainous island country and it is often subject to rapid temperature fall. Major snows throughout the southern and eastern South Island have a frequency of $3.4 \%$ (every 30 years), while within particular districts frequency varies from 13 to $22 \%$ (every 5 to 8 years) (Burrows 1976). As precipitation declines from a maximum close to the main divide, it becomes more erratic in occurrence and volume. As well as the driest areas in New Zealand within some of the Central Otago block mountain and semi-arid basin country, the high country includes localities of highly variable precipitation in the sub-humid sectors of basins such as the Upper Waitaki. This phenomenon, coupled with high evaporation under nor-wester Foehn conditions, generates both experience of and reputation for droughtiness, probably more than would be expected from mean annual precipitation itself.

Seasonal contrasts and meteorologic variability are not the only sources of variation. Aspect and elevation have major influences on temperature and in some situations on precipitation as well. Sheep and shepherds seem to be well aware of such influences. These are common, unifying features of the physical environment of high country pastoral farming. The ways they occur in any one district are varied and thereby greatly influence the practical decisions that land administrators and pastoral farmers have had to make at various times in the past, essentially summed up in what was called "balance of country". Concern about this quality has often been at the root of pastoral farmers' reluctance to relinquish high altitude lands or other lands sought for some conservation purpose. The practice of pasture improvement on montane zone terrain has altered but not removed this need for "balance".

\section{Pastoral occupation, settlement and decline}

The common cultural element in the high country is that almost all pastoral enterprises have been based on sheep, especially but not exclusively for fine wool production. The entire area of the present pastoral high country was taken up as runs in a less than a decade from 1856 to 1865 (O'Connor \& Kerr 1978). From examination of records in several districts, it appears that maximum sheep population on any property was achieved within 25 years. For all catchments and counties for which records have been examined, it appears that range sheep populations began to decline within a very few years of the maximum being reached (O'Connor 1986). The common feature of traditional pastoralism before substantial pasture improvement, was overall gradual decline in livestock production, sheep numbers 
sometimes showing temporary recovery in response to declining product prices, especially in the Great Depression, sudden falls in numbers often occurring with climatic disasters such as big snows. Progressive decline in range carrying capacity was generally more serious and prolonged in drier counties such as Maniatoto, or in drier sectors of large counties such as Mackenzie. For 100 years from occupation, pastoralists and public administrators alike seemed locked in decline of an industry from which there seemed little prospect of escape, but for which hope continued to spring eternal (O’Connor et al, 1986).

\section{Distribution of problems and their perception}

Problems have not been evenly and constantly distributed in the high country. Rabbit infestation has not been universal in all districts, nor has it been constant in time. What is reckoned as the third major rabbit plague would probably have put an end to pastoralism in drier districts by the early $1950 \mathrm{~s}$, but for the intervention of 1080, aircraft, and rabbit boards with a killer policy. Elsewhere pastoral use would probably have survived but a few decades longer, if it had not been for the discovery of sulphur and phosphorus deficiencies and the economic means for their correction for pasture growth. Before the soil fertility research of the $1950 \mathrm{~s}$ and $1960 \mathrm{~s}$, the difference between lower rainfall country and higher rainfall country was seen in vegetation depletion and more serious rabbit problems at low rainfall, in contrast with vegetation deterioration through scrub weed ingress and loss of pasture quality in the higher rainfall land. Now the low rainfall land would be recognised for needing only sulphur for its soil fertility amendment for legumes, which would remain at risk of loss through drought. The higher rainfall land of poorer soil fertility would be reckoned to need phosphorus and molybdenum as well as sulphur. Land of intermediate rainfall, from about 600 to $1000 \mathrm{~mm}$ per annum, would now be reckoned to have the most severe Hieracium problem and perhaps the highest risk of soluble soil aluminium affecting pasture growth.

\section{Variety of pastoral opportunity}

Not every pastoral farmer has had the same opportunities to maintain or restore economic well being in the face of a declining natural pastoral resource. Individual holdings varied greatly in effective size or stock-carrying capacity from the outset, chiefly by use of dummying to circumvent the limits imposed by provincial governments. Run boundaries, whether natural or fenced, were invested with a stiff dose of sacrality. Territories were defined, their integrity to be defended. Under the socio-political pressure for "bursting up the great estates", large lowland properties, resulting from earlier colonisation, either ministered to their own subdivision or were dealt with as part of land reform from 1890. The high country was exempted but not totally excluded from this process. Under the influence of John Mackenzie as Minister of Lands (Brooking 1996), a strong note of egalitarianism emerged that fostered runs of similar capacity, for equality of opportunity. An even stronger note of realism was evident after the great snow of 1895, to ensure the survival and recovery of large sheep runs as well as small.

Considerable variation in size of flocks remained. Some pastoral properties such as Benmore in the Upper Waitaki resisted subdivision until 1916, even longer than the famous Morven Hills. Such homeostasis was matched by the self-view of the pastoralists themselves. Through successive commissions of inquiry involving the high country, they saw themselves as runholders and graziers rather than as farmers, an attitude which was respected officially, all the way to the Land Act of 1948. Such an attitude did not mean that they cared not for their land. They cared for it differently from the care of lowland farmers.

Natural and man-made differences among runs in resource endowment have persisted, and even been magnified under pasture improvement regimes. The different physiography of different districts, together with the varied socio-political pressure for land for closer settlement, dependent in part on alternative livelihood opportunities towards the turn of the last century, greatly affected the subdivisions carried out by the Crown. For example, many of the gorge runs of Canterbury have had little property subdivision since establishment last century. Elsewhere subdivision often gravely affected later viability as unimproved runs and resulted in later amalgamation. Sometimes the stresses of small property size were mitigated by new technology of pasture improvement, sometimes not so. For example, as the Otago goldfields ran out, there was considerable pressure on the Crown to make more land available there for settlement, both as small grazing runs and as partly irrigated farms and orchards. Some resulting property subdivisions were eventually countered by purchase of lowland farmlands earlier separated from the run. Others have not had the opportunity to reconstitute a better balance to the pastoral property. What is clear is that well-intentioned land reforms in the past have had varied, but with often substantial influence on the residual opportunities for pastoral development in recent years. This has in turn affected the ability of lessees to meet the costs of rabbit control, to engage in negotiations for exchange of property rights affecting nature conservation interests, or to invest in alternative enterprises. 


\section{Pastoral renaissance and market forces}

\section{Role of individual leaders and change-agents}

No outline of the historical influences on the present high country situation would be complete without noting the pastoral renaissance which has been so evident over the last 30 to 40 years. S.H. Saxby had established clovers by oversowing tussock grasslands in Otago before World War II, but had doubted the economy of the practice. The role of individual farmers who led by example in finding and establishing new ways of pasture improvement and management cannot be overstated. Outstanding for his innovative ideas on pasture improvement and utilisation, control of rabbits and integration of forestry into high country farming was R.K. Ireland, flour-miller of Oamaru whose Ribbonwood run at Omarama became famous (Ireland 1952). There were others in other districts, men like David McLeod on Grassmere, Joe Allen, Ron Hosken and Ian Wardell in the Mackenzie, Bill Chisholm on Molesworth, Malcolm Prouting on Mesopotamia, Les Struthers on Mt Grand at Hawea, and some who ventured even their financial futures as well as their community standing in new options with new aerial technology.

In the pre-Orwellian world before treasury-speak of 1984, such venturesome farmers did not long have to work alone or wait until they could formulate a business plan for engaging scientific services. There were imaginative scholars like T.W. Walker, charismatic public-purse-provided farm advisers and field scientists like Tom Sewell in Canterbury and later in Southland, Harry Sievwright in the Mackenzie, Alan Dingwall and Les Bennetts in mid Canterbury, Russell Lobb in coastal and North Otago, John Hercus, John Tothill, Jim BruceSmith and Terry Ludecke in Central Otago.

Like the innovative farmers with whom they worked, such men came with different experience and sometimes quite different training, united by a shared goal of pasture improvement in the high country. They kept in touch with one another, with the botanists and foresters, soil chemists and soil conservators alike. Together, farmers with field scientists and advisers began a change in pastoral practice that was outside the scope of the new law for pastoral land, a law so proudly extolled for the secure tenure it bestowed as well as the good husbandry which it enjoined. The new pastoral practice of fertilising legume-based pastures in the high country grew to become an accepted pivot to soil conservation and land use policy, latched on to or shared in, sometimes belatedly, by national and local authorities. It is ironic that it is now so taken-for-granted as to be doubted or derided by some new apostles of biodiversity who have little idea of the nature destruction that the new practice averted.

\section{Improvement in pastoral productivity}

Contrary to some of the myths shared by some interest groups, the high country has continued to improve in pastoral productivity. Figure 1 suggests that over the last three decades, there has been a substantial upward trend in production of wool per farm and even in numbers of sheep and lambs sold per farm in the high country sector. We estimate from the less frequent but larger census of high country runs by the former Tussock Grasslands and Mountain Lands Institute, that over the same period the total livestock wintered on high country has almost doubled, to be close to 3 million stock units. Together these statistics show substantial growth in pastoral productivity. Analyses of pastoral utilisation records from more than 50 runs in the late 1970s, support a general relationship that indicates that some $80 \%$ of the feeding of high country livestock then came from improved legume-based pastures on less than $20 \%$ of the land. These estimates, combined with the estimates above of growth in pastoral productivity, speak volumes for the effectiveness of the pasture improvement practice.

Figure 1 Trends in high country pastoral run production over the last three decades. Wool production (solid) and sheep plus lambs sold per run (dotted). Source: Annual "Sheep and beef farm survey" of NZ Meat and Wool Boards' Economic Service, data for the South Island high country sector.

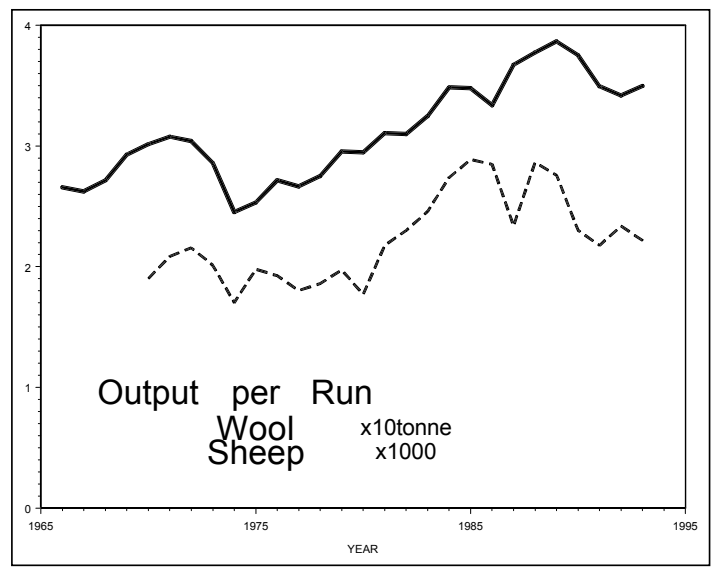

Market forces affecting wool, inputs and alternative land products

Increased production of wool and of sheep for sale over the last three decades has not brought commercial rewards, because of continued deterioration in wool prices and the associated effect on store sheep prices. Long-term trends in New Zealand export wool prices, export sawn timber prices and labour costs, as 
exemplified by shearing costs, are shown in Figure 2. Against a static or declining level of wool price is a generally upward trend in labour costs and a similar upward trend in export timber values. Past records of both wool and timber prices show long-term cyclical trends, of the order of two decades, and large year to year fluctuations, somewhat smoothed in the graphs presented. Recent upward trends for timber contrast with those for wool which have been markedly downward.

Figure 2 Trends in New Zealand export wool prices, export sawn timber prices, and shearing rates since 1857 , adjusted to 1994 values with a degree of smoothing.

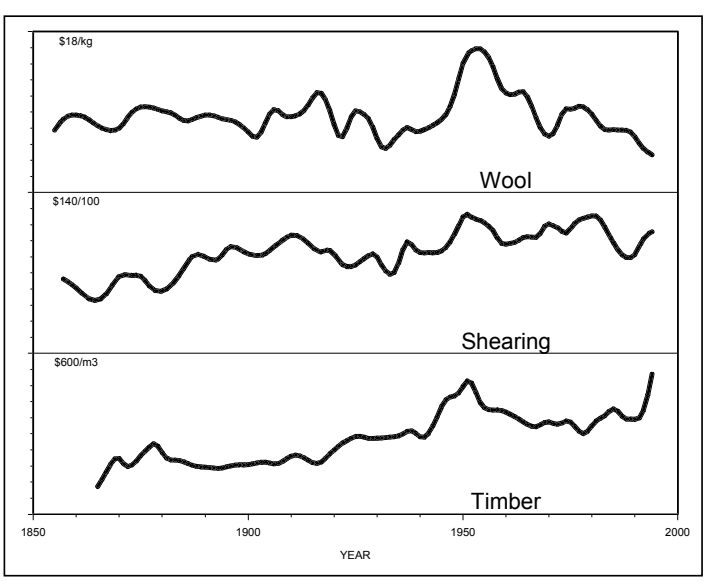

Since the 1960s the price advantage (relative to 37 micron crossbred) for 19 micron wool has averaged $\mathrm{x} 2.4$, and $\mathrm{x} 1.8$ for 21 micron wool, but the general trend in price is similar and fine wools have had greater year to year fluctuation (Jarvis \& Davison 1995). Hopes for price improvement are dampened by the size of the Australian stockpile. As an indicator of labour costs, which are a high but perhaps declining proportion of farm costs in the high country sector, shearing rates show an upward trend in comparison with wool prices. Other input costs have been rising as high country farming has been increasingly mechanised and in other ways modernised. By the mid 1980s fertiliser use per livestock unit in the high country was of the same order as that for most other classes of sheep farming.

Against such an input cost versus product price squeeze, high country farmers would be expected to be interested in opportunities to diversify their land use somewhat from their continuing 65 to 70 per cent income dependence on wool. It may seem strange that there are such protracted delays to the legislative changes in tenure and to district scheme changes that would make it possible for farmers to become involved in complementary or alternative land uses on the land to which they have secure and renewable title. It is not as if governments have not been told and indeed recognised that the 1948 Land Act, even with all its fiddly amendments, is an anachronism. It is hardly credible to conceive that to allow market forces to have more influence on high country land use is out of keeping with current governmental thinking. Perhaps there are other forces which have a different kind of market place or forum and a different token of exchange from those for which we trade with in dollars.

\section{Myths and icons}

The high country has not been short of myths. The issues that emerge from examination of the present situation are as much the outcome of the myths that society has moulded as they are the result from realworld interaction of ecologic and economic factors such as we have outlined. Myths sometimes develop as the aspirations of the silent. They are often independent of historical accuracy. They are stories we want to believe because of the inspiration they give us. Sometimes they are nourished and encouraged by public propaganda, as we witnessed in Nazi Germany, as we discern in advertising campaigns and media presentations in our own time. Sometimes the way they grow and possess the minds of people deviates substantially from the seeds of fact or imagination from which they spring. Myths are not to be set aside and discounted. Rather they should be as carefully examined as landforms, soils and trophic systems for the meanings that they hold, the values which they reflect of those who believe in them. Only by knowing facts and knowing values and confronting these different kinds of knowledge with each other will we be able to discern and treat the issues with which they are so often confounded.

The Mackenzie affair illustrates how "half a fairy tale" could grow to provide social insights and aspirations of early pastoral times quite beyond the scope of formal reporting. There was a John Douglass alias James Mackenzie captured by the agents of Canterbury Plains pastoralists, tried and jailed for sheep stealing in 1855, but fully pardoned 10 months later, in what was apparently one of New Zealand's first miscarriage of justice cases. In the myths that developed, the times are imaged:

Behind the 'phantom rustler', behind the desperation and the gaol-breaks, one senses the cry of the (then) landless, the grievance of the small-farmer, the plight of the undefended bundled into rotten gaols and the resentment against a hierarchical 
system which protected wealth, rank, and privilege.

(McNeish 1972)

Interestingly, shepherds and pastoral landholders also ascribed to the legendary Mackenzie the characteristics they sought in themselves: "the best dogman in the world", "a marvel of a shepherd", "he crossed all them rivers", "resourceful", "independent". Thirty years ago, you could meet people in South Canterbury who claimed to have had a pup from one of his beloved black bitch's own offspring. Now you can stand at the memorial Church of the Good Shepherd at Tekapo and hear tourists explain to one another that the bronze image on the stone cairn is of Mackenzie's dog!

Fifty years ago, the national icon from the high country was the high country shepherd or the working runholder, working dogs and sheep. Soon that icon was joined by one more personal, more famous, the mountaineer of Everest. Now the shepherd has become scarcely distinguishable among the other "good keen men", and "good keen women", of the back country such as the parapenter, board-ski rider, mountain cyclist, ironman athlete, bungy jumper, tramper and downhill skier. Iconography becomes confused, like the issues. Clover as a symbol of something new in high country pastoral farming, or two grass blades growing where there was one rolled-leaf tussock before, have been joined by Douglas fir, deer paddocks, farm stays, fourwheel-drive safaris and niche-siting of 'second-homes', orchards and vineyards. These may be the ideas of those who hold the land and seek to promote its sustainable management in their own lights and to the satisfaction of local authorities. A waving tawny tussock is more likely to become the not-so-hidden high country icon of the increasingly preservationist, now-not-so-silent urban landless. In heraldic form it might have as kaitiaki a large Otago skink on an adjacent leaning rock, rather than a border collie. Kea and falcon would circle above. Takahe and weka might forage among its tillers.

In truth, all of these icons can be honoured, but not all at once and in the same place. The real issues will be as before: what are grand hills for sheep and where may sheep safely graze; what should be reforested and how; where should nature be protected and for what purposes and who should protect it; where and how may people make their way for mountain recreation without trespass but with responsibility for their safety and consequences; who shall pay which piper and who shall call the tune?

\section{REFERENCES}

Brooking, T. 1996. Lands for the People? The Highland Clearances and the Colonisation of New Zealand: a biography of John McKenzie. Dunedin: University of Otago Press.

Burrows, C.J. 1976. Exceptional snowstorms in the South Island high country. Review Tussock Grasslands and Mountain Lands Institute 32: 4347.

Ireland, R.K. 1952. Tussock grassland: marginal land. Proceedings of the New Zealand Grassland Association 14: 138-144.

Jarvis, P.J.; Davison, R.M. 1995. A review of high country production and performance from 1967 to 1995 with particular reference to changes in nominal and real product prices and government policy framework which affected farmers over the period. New Zealand Agricultural Economics Society Conference Papers.

McGlone, M.S. 1988. New Zealand. pp.557-599. In: Huntley, B. and Webb, T. (eds), Handbook of vegetation science 7. Vegetation History. Dordrecht: Kluwer Academic Publishers.

McNeish, J. 1972. The Mackenzie Affair. Auckland: Hodder and Stoughton.

O'Connor, K.F. 1986. The influence of science on the use of tussock grasslands. Review Journal of the Tussock Grasslands and Mountain Lands Institute 43: 15-78.

O'Connor, K.F.; Kerr, I.G.C. 1978. The history and present pattern of pastoral range production in New Zealand. pp. 104-107. In: Proceedings of First International Rangeland Congress, Denver, Colorado, 14-18 August.

O'Connor, K.F.; Lochhead, L.E.; Kerr, I.G.C. 1986. Administrative and managerial responses to changes in economic and ecologic conditions in New Zealand tussock grasslands. pp. 97-101. In: Joss, P.J.; Lynch, P.W.; Williams, O.B. (eds), Rangelands: a Resource under Siege. Proceedings of the Second International Rangeland Congress. Adelaide, Australian Academy of Science, Canberra.

Wardle, P. 1991. The Vegetation of New Zealand. Cambridge: Cambridge University Press. 
